Sains Malaysiana 50(3)(2021): 869-878

http://dx.doi.org/10.17576/jsm-2021-5003-27

\title{
Analisis Status Alam Sekitar semasa Tempoh Perintah Kawalan Pergerakan Akibat Pandemik COVID-19 di Malaysia
}

(Analysis of Environmental Status during the Movement Control Order Period due to COVID-19 Pandemic in Malaysia)

\author{
JefFrey Lawrence D’Silva*, Haliza Abdul Rahman \& Dzuhailmi Dahalan
}

\begin{abstract}
ABSTRAK
Alam sekitar adalah antara agenda utama ke arah mencapai pembangunan mampan dalam sesebuah negara. Sungguhpun isu ini penting, namun bilangan kajian yang berkaitan dengan status alam sekitar mengikut pandangan masyarakat masih berkurangan dalam konteks Malaysia. Untuk mengatasi masalah ini, matlamat utama kajian ini adalah untuk mengkaji status alam sekitar khasnya semasa tempoh perintah kawalan pergerakan akibat pandemik COVID-19 dan mengenal pasti faktor yang boleh mempengaruhi status alam sekitar di Malaysia. Kajian ini berbentuk kuantitatif dengan pengumpulan data dilakukan melalui survei dalam talian dengan jumlah responden seramai 507. Hasil kajian menunjukkan status alam sekitar bertambah baik semasa tempoh perintah kawalan pergerakan akibat pandemik COVID-19 disebabkan penggunaan bahan api fosil dan bilangan kenderaan di jalan raya telah berkurangan. Sementara itu, perkara yang perlu diberi perhatian adalah mengenai keadaan sungai dan pengurusan sisa klinikal oleh Pihak Berkuasa Tempatan. Kajian ini mencadangkan tiga perkara yang boleh dilaksanakan untuk kelestarian alam sekitar iaitu untuk meneliti bidang keutamaan ekonomi negara, menggalakkan penggunaan pengangkutan awam dan pengurusan sisa klinikal yang lebih cekap.
\end{abstract}

Kata kunci: COVID-19; masyarakat; perintah kawalan pergerakan; status alam sekitar

\section{ABSTRACT}

The environment is one of the main agenda towards achieving sustainable development in a country. Although this issue is important, the number of studies related to environmental status based on public opinion is still lacking in the Malaysian context. To address this issue, the main aim of this study was to investigate the environmental status especially during the movement control order period due to COVID-19 pandemic and identify factors that may affect environmental status in Malaysia. This is a quantitative study and the data were collected through online survey and the number of respondents was 507. The findings showed that the environmental status improved during the movement control order period due to COVID-19 pandemic since the usage of fossil fuel and the number of vehicles on the road decreased. Meanwhile, more attention should be placed on the condition of the rivers, and the management of clinical waste by the Local Authority. The study proposes three things that can be done for environmental sustainability, namely, to examine areas of national economic priorities, promote usage of public transport, and more efficient clinical waste management.

Keywords: Community; COVID-19; environmental status; movement control order

\section{PENGENALAN}

Agenda pembangunan masa kini adalah berpaksikan kepada pembangunan mampan. Alam sekitar merupakan komponen utama kepada pembangunan mampan selain daripada aspek ekonomi dan sosial (D'Silva \& Samah 2018). Sejak kebelakangan ini banyak usaha telah dilaksanakan untuk meningkatan kemajuan dalam bidang ekonomi sehingga menjejaskan usaha untuk mencapai kelestarian hidup. Natijahnya, alam sekitar terus mengalami kemerosotan dari hari ke hari akibat sikap manusia (Rahman 2018) dan kegiatan pembangunan ekonomi yang banyak bergantung kepada kegiatan perindustrian untuk kelangsungan hidup.

Tidak dapat dinafikan alam sekitar amat penting kepada kesejahteraan manusia khasnya daripada aspek kesihatan dan keselamatan (Rahman \& Lee 2020). 
Perubahan iklim yang ketara, pembuangan sampah sarap dan sisa toksik secara haram ke dalam sungai, udara yang tercemar akibat daripada peningkatan dalam kegiatan perindustrian dan bilangan kenderaan yang meningkat di jalan raya dan pelepasan sisa kimia dan toksik ke dalam sungai sehingga menjejaskan bekalan air mentah ternyata mengancam ekosistem kehidupan manusia (Ng et al. 2020; Shafie \& Mahmud 2020).

Terkini, dunia digemparkan dengan jangkitan wabak koronavirus. Namun sedarkah kita bahawa pencemaran alam sekitar sebenarnya jauh lebih berbahaya kerana ia adalah pembunuh senyap dan dikaitkan dengan pelbagai penyakit. Angka kematian akibat pencemaran alam sekitar jauh melebihi angka kematian daripada peperangan di serata dunia, namun kita jarang memberi perhatian sewajarnya disebabkan kekurangan pengetahuan dan kesedaran tentang kesannya kepada kesihatan.

Menyedari kepentingan alam sekitar kepada kesejahteraan manusia, kerajaan Malaysia telah mengambil pelbagai inisiatif untuk memelihara dan memulihara alam sekitar negara. Ini termasuklah penggubalan beberapa dasar berkaitan seperti Dasar Alam Sekitar Negara 2002, Dasar Perubahan Iklim Negara 2009 dan Dasar Kepelbagaian Biologi Negara 1998. Ini diikuti dengan pewartaan pelbagai perundangan bagi melindungi alam sekitar daripada terus dicemari secara berterusan, antaranya Akta Kualiti Alam Sekeliling 1974, Akta Perhutanan Negara 1984 dan Akta Pemuliharaan Hidupan Liar 2010. Malahan pelbagai strategi, langkah dan tindakan dilakukan untuk meningkatkan penglibatan masyarakat Malaysia ke arah usaha menjaga dan melindungi alam sekitar, namun ternyata usaha ini 'kurang mendapat sambutan' dalam kalangan masyarakat. Pelbagai alasan diberikan, antaranya kesibukan seharian, tidak mempunyai masa, kurang berminat dengan isu alam sekitar serta kesukaran mendapatkan maklumat tentang alam sekitar. Sekiranya laporan dibuat terhadap mereka yang mencemari persekitaran, masyarakat sering beranggapan tindakan sewajarnya gagal diambil oleh pihak berkaitan selain kes mengambil masa yang lama untuk didakwa.

Hal ini menunjukkan, walaupun banyak usaha berterusan telah dilaksanakan, tren pencemaran alam sekitar masih menjadi isu kritikal dalam konteks Malaysia dan memerlukan kajian yang berterusan bagi mencapai kemampanan alam sekitar (Sentian et al. 2019). Justeru, terdapat beberapa kajian lepas yang telah dilakukan untuk meninjau pengetahuan, sikap dan amalan masyarakat Malaysia mengenai penjagaan alam sekitar dengan dapatan yang pelbagai (Chin et al. 2019; Haliza et al. 2015).

Terkini, pandemik COVID-19 yang melanda dunia telah memberi kesan positif kepada status alam sekitar fizikal (seperti peningkatan kualiti udara dan air sungai). Justeru, persoalan yang timbul ialah adakah kesan peningkatan status kualiti alam sekitar tersebut turut membawa peningkatan yang positif terhadap tahap kepekaan dalam kalangan masyarakat terhadap isu pemuliharaan alam sekitar masyarakat di Malaysia.

Maka, tujuan utama kajian ini dilaksanakan ialah untuk meninjau pandangan masyarakat Malaysia terhadap status alam sekitar semasa tempoh Perintah Kawalan Pergerakan (PKP) ketika pandemik COVID-19, di samping melihat sama ada terdapat perbezaan atau perkaitan yang signifikan antara pemboleh ubah tertentu dengan pandangan masyarakat terhadap alam sekitar. Kajian ini mempunyai beberapa signifikan. Pertama, ia menyumbang kepada korpus ilmu kerana maklumat yang diperoleh daripada kajian akan menunjukkan sama ada berlaku perubahan daripada segi sikap dan amalan di kalangan masyarakat Malaysia berhubung status alam sekitar melalui pengalaman yang dilalui semasa PKP ketika pandemik COVID-19. Di samping itu, hasil kajian ini turut menyumbang input kepada penggubal polisi untuk memperkasa program baharu yang lebih konkrit bagi meningkatkan lagi kesedaran komuniti ke arah pemuliharaan dan pemeliharaan alam sekitar.

\section{SOROTAN KEPUSTAKAAN}

Alam sekitar yang seimbang dan sihat adalah penting bagi membolehkan manusia memperoleh piawai hidup yang menyediakan keselesaan, keamanan dan kepuasan (Aiken et al. 1982). Persepsi masyarakat terhadap persekitaran memainkan peranan penting terhadap kelestarian persekitaran khususnya pada skala tempatan. Persepsi masyarakat ditentukan oleh beberapa faktor seperti pengalaman hidup, sikap, nilai, suara hati dan kehendak yang mana ia melibatkan pengalaman kehidupan individu (Rasmussen 1999). Natijahnya, masyarakat sebagai tonggak atau aktor utama ke arah pelestarian alam sekitar perlu berperanan secara aktif demi memastikan khazanah alam sekitar terus terpelihara dan terpulihara. Ini kerana pengurusan alam sekitar yang lestari tidak mungkin berjaya tanpa mendapat kerjasama daripada masyarakat (Haliza 2015). Justeru, masyarakat harus berperanan dan terlibat secara aktif dalam usaha melindungi alam sekitar. Semua ini menuntut masyarakat seluruhnya memahami etika alam sekitar dalam usaha memandu interaksi antara manusia dengan alam sekitar (Haliza 2009). Menurut Haliza (2009), etika persekitaran mampu membataskan perlakuan dan tingkah laku masyarakat terhadap alam sekitar kerana etika persekitaran akan memberikan kesedaran kepada masyarakat tentang apa yang sepatutnya boleh dilakukan atau tidak sepatutnya dilakukan terhadap alam ini. Jika kesemua aspek alam sekitar ini berada dalam keadaan yang baik dan memuaskan, masyarakat pada umumnya boleh hidup sihat dan berasa selesa. 
Menurut Haliza (2018), sejak sekian lama aktiviti pembangunan sering kali dikaitkan dengan kemerosotan kualiti persekitaran. Ini kerana matlamat utama pembangunan adalah untuk meningkatkan taraf ekonomi dan kualiti hidup manusia. Justeru, bagi merealisasikan hasrat ini alam sekitar dan sumbernya kerap kali dieksploitasi secara keterlaluan dan tidak mampan sehingga menimbulkan kemerosotan dan kemusnahan yang serius pada alam sekitar. Maka, fungsi perancangan dan pengurusan pembangunan perlu ditakrifkan dengan berkesan dan terperinci bagi memastikan supaya amalan perancangan, penggubalan dasar dan pengurusan pembangunan menjadi lebih berkesan bagi mengimbangi peningkatan ekonomi dan pemeliharaan alam sekitar (Haliza 2018). Ini selari dengan Agenda 21 yang terhasil daripada Persidangan Rio pada tahun 1992 bermatlamat untuk menghentikan dan mengendurkan proses kerosakan alam sekitar ke atas bumi ke arah menggalakkan pembangunan yang selamat dan mampan di semua negara di seluruh dunia (Haliza 2018).

Berikutan itu, ukuran pembangunan yang sering berpaksikan ekonomi beralih arah kepada berpaksikan manusia dengan matlamat pembangunan yang baharu, iaitu untuk meningkatkan kesejahteraan manusia, dengan pendekatan pembangunan mampan (Haliza 2018). Pembanguan mampan adalah satu istilah popular di peringkat global mahupun Malaysia, namun sejauh mana masyarakat benar-benar memahami dan mempraktikkan usaha ini? Walaupun istilah tersebut diperkenalkan lebih tiga dekad yang lalu, namun pencapaiannya ke arah dunia yang lestari dilihat masih tidak memberangsangkan (O’Neill \& McElroy 2017).

Hakikatnya, konsep pembangunan mampan diperkenalkan kerana dunia dihantui kegusaran akibat kemusnahan alam sekitar secara berleluasa disebabkan oleh pelbagai aktiviti manusia yang kurang menitikberatkan aspek kemampanan dalam segala tindak tanduk mereka (D'Silva et al. 2018). Maka, mulai tahun 2015, konsep ini telah diperluaskan di peringkat global dengan tercetusnya Matlamat Pembangunan Mampan (SDGs) 2030 yang terdiri daripada 17 matlamat utama dan perlu dicapai menjelang tahun 2030. Pembangunan mampan 2030 meletakkan penjagaan alam sekitar sebagai antara kriteria utama ke arah melahirkan masyarakat dunia yang sejahtera. Dalam konteks ini, antara matlamat yang perlu dicapai daripada sudut alam sekitar adalah memastikan pengurusan air mampan, mengambil tindakan segera untuk menangani perubahan iklim, memelihara dan memulihara kehidupan di laut dan darat dan memastikan kehidupan sihat. Malaysia juga tidak terkecuali serta turut bertanggungjawab di dalam memastikan segala matlamat pembangunan mampan tercapai menjelang tahun 2030. Namun begitu, ini bukanlah satu tugas yang mudah kerana kemajuan daripada segi ekonomi khasnya dengan revolusi industri 4.0 dan era perindustrian digital sedikit sebanyak mengekang matlamat pembangunan mampan 2030. Oleh itu, pemupukan nilai etika alam sekitar sangat penting kerana ia mampu membina persepsi masyarakat milenium untuk bertindak matang dalam merancang pembangunan tanpa mengabaikan prinsip keberterusan sumber (Haliza 2009). Pelbagai tindakan boleh dilakukan untuk menggalakkan pembangunan mampan bagi menjamin keberterusan sumber. Antaranya menggalakkan pemuliharaan sumber, mengelakkan pembaziran sumber serta mengimbangi pembangunan fizikal dan sosial (Ahmad Shukri \& Rosman 2003). Penerapan nilai etika alam sekitar dilihat turut mampu menjamin keselesaan kepada penghuninya melalui persekitaran yang bersih, nyaman dan segar (Haliza 2009).

Kebelakangan ini, dunia dikejutkan dengan satu lagi pandemik iaitu wabak penyakit koronavirus yang memberi impak global kepada dunia. Puluhan nyawa telah terkorban. Namun begitu, cabaran menangani penularan pandemik COVID-19 telah memberi kesempatan kepada kerajaan di peringkat global melakukan perubahan struktur yang disifatkan sebagai penting dalam usaha mewujudkan pembangunan yang lebih mampan, dinamik serta inklusif termasuk berkaitan alam sekitar. Pada masa yang sama, banyak iktibar dan penambahbaikan dijangka dapat diambil oleh kerajaan dan masyarakat untuk terus prihatin terhadap kepentingan memulihara dan melestarikan alam sekitar (Jamil et al. 2020)

Tinjauan kepustakaan menunjukkan sebanyak 33,000 artikel jurnal telah dihasilkan dalam konteks masyarakat Malaysia mengenai isu alam sekitar dari tahun 2016 sehingga kini. Data ini membuktikan tentang keseriusan isu ini di Malaysia. Namun begitu, tinjauan menunjukkan kajian mengenai persepsi masyarakat terhadap alam sekitar amat berkurangan (Chin et al. 2019). Antara fokus kajian yang dilakukan oleh penyelidik tempatan berkaitan dengan isu alam sekitar ialah daripada segi persepsi, pengetahuan, sikap dan amalan masyarakat (Haliza 2019).

Menurut Zaini (2007), bagi melahirkan masyarakat yang terdidik dengan amalan kehidupan yang mesra alam, tumpuan harus diberikan kepada lima aspek utama iaitu: Memupuk cara pemikiran masyarakat supaya menghargai alam sekitar; Melaksanakan kempen dan promosi secara intensif melalui pelbagai kaedah dan media; Memastikan setiap individu dalam masyarakat menghayati amalan dan cara hidup yang mesra alam; Penghayatan konsep kelestarian dalam konteks keluarga, organisasi dan masyarakat; dan Mewujudkan masyarakat mesra alam dengan menjadikan bidang alam sekitar sebagai sesuatu yang amat penting dalam dasar utama kerajaan. 
Untuk itu, Teori Kelakuan Terancang merupakan suatu model umum yang baik bagi menghurai gelagat manusia. Teori ini menyatakan terdapat hubungan positif antara niat dan tindakan manusia. Dalam konteks penelitian alam sekitar dan COVID-19, sekiranya masyarakat mempunyai persepsi yang baik terhadap alam sekitar dan kepentingan menjaganya, maka semakin kuat kebarangkalian ahli masyarakat untuk memberi perhatian yang serius terhadap penjagaan alam sekitar pada masa hadapan.

Dalam kebanyakan kajian mengenai alam sekitar, antara komponen yang dititikberatkan adalah kualiti udara, sungai yang bersih dan hutan yang terpelihara (Desa et al. 2009). Di samping itu, aspek seperti pembuangan dan penyelenggaraan bahan buangan, bekalan air yang bersih, penggunaan bahan api fosil dan gangguan daripada haiwan peliharaan dan ternakan turut tersenarai dalam beberapa kajian. Di peringkat global, Organisation for Economic Cooperation and Development (OECD) melihat indikator pengukuran alam sekitar merangkumi komponen perubahan cuaca, kualiti udara, pengurusan air, pengurusan hutan, pengurusan tenaga, flora dan fauna dan pengurusan sisa. Sebagai tambahan, sesetengah pengkaji turut menyatakan terdapat beberapa faktor sosio-demografi turut mempunyai hubungan langsung atau perbezaan signifikan dengan kesedaran alam sekitar. Sebagai contoh, jantina, umur, dan tahap pendidikan masyarakat.

\section{METOD}

Kajian ini merupakan kajian keratan rentas melibatkan masyarakat Malaysia yang berumur 18 tahun ke atas. Kajian kuantitatif ini menggunakan borang soal selidik dalam talian sebagai alat pengumpulan data. Soal selidik ini dibina berdasarkan kajian lepas (Haliza 2019, 2017; Haliza \& Mohammad Ghazi 2012) dengan menyesuaikannya dengan konteks pengukuran persepsi masyarakat terhadap alam sekitar ketika PKP akibat pandemik COVID-19. Validasi soal selidik ini adalah berdasarkan kepada perbincangan kata sepakat dalam kalangan ahli penyelidik yang juga merupakan pakar bidang dalam isu yang dikaji. Setelah itu, Exploratory Factor Analysis (EFA) dilakukan untuk tujuan pemurnian konstruk pengukuran melalui penyingkiran item yang tidak memenuhi kriteria dalam analisis statistik. Anggaran jumlah populasi untuk kajian ini ialah dalam lingkungan 20 juta rakyat Malaysia yang berumur 18 tahun ke atas berdasarkan data Jabatan Statistik Malaysia (2020). Berdasarkan kepada tahap keyakinan (95\%) dan margin kesilapan (5\%), saiz sampel sepatutnya dibolehkan pada sekitar 384 orang responden. Justeru, jumlah responden yang terlibat dalam kajian ini adalah seramai 507 orang. Purata skor peratusan semua item telah digunakan bagi menentukan status semasa alam sekitar ketika tempoh PKP akibat pandemik COVID-19. Pengukuran status alam sekitar pula berdasarkan kepada tiga tahap iaitu: 1-39.99 (Kurang baik); 40-59.99 (Sederhana baik); 60-79.99 (Baik) dan 80-100 (Sangat Baik). Data kajian diinput dan dianalisis menggunakan perisian SPSS versi 25 dan Microsoft Excel. Hasil kajian turut menggunakan analisis statistik deskriptif dan inferensi (ujian-t bebas dan korelasi Pearson).

\section{KePUTUSAN DAN PERBINCANGAN}

Jadual 1 menunjukkan taburan demografi responden. Data menunjukkan min umur responden ialah 38.1 tahun. Secara terperinci, majoriti responden $(62.1 \%)$ berada dalam lingkungan umur 31-40 tahun, diikuti sebanyak $21.5 \%$ dalam lingkungan umur 41-50 tahun. Ini disusuli dengan 6.7\% mewakili umur antara 21-30 tahun dan 5160 tahun. Hanya $2.0 \%$ responden berumur lebih daripada 60 tahun manakala $1.0 \%$ responden berumur 20 tahun dan ke bawah. Keputusan ini selari dengan kajian yang dibuat oleh Muller (2020) yang menunjukkan kumpulan umur di bawah 40 tahun merupakan kumpulan umur paling signifikan menggunakan internet di Malaysia dan ini adalah selaras dengan metod kajian yang menggunakan survei dalam talian.

Pecahan responden berdasarkan jantina pula menunjukkan $63.1 \%$ merupakan perempuan, selebihnya (36.1\%) adalah lelaki. Walaupun kajian yang dibuat oleh Suruhanjaya Komunikasi dan Multimedia Malaysia (2018) menunjukkan pengguna lelaki lebih ramai dalam penggunaan internet berbanding perempuan, keputusan kajian semasa menunjukkan responden perempuan lebih responsif kepada isu alam sekitar berbanding lelaki menggunakan survei dalam talian. Selain daripada itu, $52.7 \%$ daripada responden yang terlibat sudah berkahwin, sementara bakinya $(47.3 \%)$ berstatus bujang. Berdasarkan lokasi tempat tinggal, taburan data menunjukkan peratusan responden yang menetap di bandar adalah sebanyak $47.7 \%$ berbanding luar bandar (52.3\%). Taburan demografi ini menunjukkan masyarakat Malaysia merentas lokasi (tempat tinggal) mempunyai keprihatinan terhadap isu alam sekitar. Majoriti dalam kalangan mereka menetap di rumah teres (47.3\%), diikuti pangsapuri dan kondominium (15.2\%), banglo (14.2\%), semi-D (10.3\%), jenis rumah lain-lain (7.5\%) manakala $5.5 \%$ lagi menetap di rumah pangsa. Status pekerjaan responden, menunjukkan keseimbangan dengan $57.4 \%$ dalam kalangan mereka sedang bekerja manakala selebihnya (42.6\%) tidak bekerja. Pendapatan isi rumah responden menunjukkan lebih kurang 55\% dalam kalangan mereka berpendapatan RM5,000 dan ke bawah. 
JADUAL 1. Profil demografi terpilih responden ( $\mathrm{n}=507$ orang)

\begin{tabular}{|c|c|c|}
\hline & $n$ & $\%$ \\
\hline Min umur: 38.1 & & \\
\hline 20 dan ke bawah & 5 & 1.0 \\
\hline $21-30$ & 34 & 6.7 \\
\hline $31-40$ & 315 & 62.1 \\
\hline $41-50$ & 109 & 21.5 \\
\hline $51-60$ & 34 & 6.7 \\
\hline Lebih daripada 60 & 10 & 2.0 \\
\hline \multicolumn{3}{|l|}{ Jantina } \\
\hline Lelaki & 183 & 36.1 \\
\hline Perempuan & 324 & 63.9 \\
\hline \multicolumn{3}{|l|}{ Status Perkahwinan } \\
\hline Bujang & 240 & 47.3 \\
\hline Berkahwin & 267 & 52.7 \\
\hline \multicolumn{3}{|l|}{ Lokasi Tempat Tinggal } \\
\hline Bandar & 242 & 47.7 \\
\hline Luar bandar & 265 & 52.3 \\
\hline \multicolumn{3}{|l|}{ Jenis Rumah } \\
\hline Pangsa & 28 & 5.5 \\
\hline Pangsapuri/kondominium & 77 & 15.2 \\
\hline Teres & 240 & 47.3 \\
\hline Semi-D & 52 & 10.3 \\
\hline Banglo & 72 & 14.2 \\
\hline Lain-lain & 38 & 7.5 \\
\hline \multicolumn{3}{|l|}{ Status pekerjaan } \\
\hline Tidak bekerja/pelajar/pencen/suri rumah & 216 & 42.6 \\
\hline Profesional/Eksekutif & 169 & 33.3 \\
\hline Sokongan/Bukan eksekutif & 83 & 16.4 \\
\hline Bekerja sendiri/Lain-lain & 39 & 7.7 \\
\hline \multicolumn{3}{|l|}{ Pendapatan } \\
\hline$\leq \mathrm{RM} 2,500$ & 93 & 18.3 \\
\hline RM2,501-RM5,000 & 187 & 36.9 \\
\hline RM5,001-RM7,500 & 58 & 11.4 \\
\hline RM7,501-RM10,000 & 101 & 19.9 \\
\hline$>$ RM10,000 & 68 & 13.4 \\
\hline
\end{tabular}


Objektif utama kajian ini adalah untuk meneliti status alam sekitar semasa PKP akibat pandemik COVID-19 daripada persepsi masyarakat. Jadual 2 meringkaskan nilai skor yang diperoleh daripada setiap item dan keseluruhan skor untuk dimensi ini. Keputusan menunjukkan status alam sekitar semasa PKP akibat pandemik COVID-19 adalah pada paras $78.75 \%$ iaitu baik. Keputusan ini sedikit sebanyak menunjukkan status alam sekitar semasa PKP akibat pandemik COVID-19 bertambah baik berbanding dengan keputusan Ahamad et al. (2014) dan Makmom et al. (2012). Momentum pengekalan alam sekitar yang baik dalam kalangan masyarakat Malaysia perlu ditingkatkan selaras dengan Teori Kelakuan Terancang supaya negara tidak berhadapan dengan masalah kelestarian alam sekitar.

JADUAL 2. Item pengukuran penelitian masyarakat terhadap alam sekitar semasa PKP akibat pandemik COVID-19

Item
Saya menerima bekalan air bersih untuk kegunaan harian di rumah saya tanpa gangguan
PKP meningkatkan kefahaman saya berkaitan kebersihan bagi menghindari penyakit
berjangkit seperti demam denggi dan sebagainya
Cuaca (suhu) di kawasan kediaman saya adalah baik ekoran pergerakan terhad penduduk
(PKP)

$\begin{array}{ccc}\text { Min (M) } & \begin{array}{c}\text { Sisihan } \\ \text { piawai (SP) }\end{array} & \text { Skor } \\ 4.37 & .788 & 84.14\end{array}$

Kawasan kediaman saya tidak terjejas dengan pencemaran udara (misalnya, debu udara, jerebu)

$4.55 \quad .683 \quad 88.64$

PKP mengurangkan jumlah pergerakan kenderaan sekaligus mengurangkan pencemaran udara di kawasan kediaman saya

$\begin{array}{lll}3.90 & .996 & 72.38 \\ 4.64 & .605 & 91.01\end{array}$

PKP mengurangkan jumlah pergerakan kenderaan sekaligus mengurangkan pencemaran bunyi di kawasan kediaman saya

$\begin{array}{lll}4.56 \quad 698 & 89.10\end{array}$

Saya dapat menjimatkan penggunaan bahan api fosil (petrol) kerana jarang keluar rumah

$4.68 \quad-617 \quad 092.03$

Pelupusan sampah sarap di kawasan kediaman oleh pihak berkuasa tempatan diuruskan mengikut jadual yang ditetapkan

$\begin{array}{lll}4.28 & .867 \quad 82.00\end{array}$

PKP tidak menjejaskan pengurusan sisa klinikal (cth: sisa dari makmal, ubat-ubatan yang tidak digunakan, pembalut luka yang tidak digunakan, dsb) oleh PBT di kawasan kediaman saya

PKP melatih saya untuk lebih teliti di dalam menguruskan pelupusan sisa pepejal di rumah

Di kawasan kediaman saya, tiada gangguan haiwan peliharaan/serangga perosak/ternakan (misalnya kucing, anjing, lembu, ayam dsb)

Kawasan kediaman saya tidak diancam dengan masalah bencana alam (misalnya, banjir, hakisan tanah)

$\begin{array}{lll}4.17 \quad & .892 \quad 79.25\end{array}$

Kawasan hijau di kawasan kediaman saya (misalnya, padang permainan, projek pertanian bandar) diuruskan dengan baik 
Analisis seterusnya meneliti item yang menyumbang kepada penelitian masyarakat tentang alam sekitar semasa PKP akibat pandemik COVID-19. Keputusan menunjukkan item yang paling menyumbang adalah mereka dapat menjimatkan penggunaan bahan api fosil (petrol) kerana jarang keluar rumah (Min=4.68; $\mathrm{SP}=.617$ ); PKP mengurangkan jumlah pergerakan kenderaan sekaligus mengurangkan pencemaran udara di kawasan kediaman mereka ( $\mathrm{M}=4.64, \mathrm{SP}=.605)$; dan PKP mengurangkan jumlah pergerakan kenderaan sekaligus mengurangkan pencemaran bunyi di kawasan kediaman mereka (M=4.56, $\mathrm{SP}=.698)$. Keputusan ini menunjukkan jumlah pergerakan kenderaan yang berkurangan semasa PKP akibat pandemik COVID-19 memberi kesan yang baik terhadap alam sekitar menurut pendapat masyarakat Malaysia. Ini disokong oleh Chin et al. (2019) yang menyatakan bahawa kenderaan bermotor mempunyai impak yang tinggi kepada pencemaran udara. Keputusan kajian semasa juga menunjukkan PKP akibat pandemik COVID-19 telah meningkatkan kefahaman masyarakat berkaitan kebersihan bagi menghindari penyakit berjangkit seperti demam denggi dan sebagainya ( $M=4.55$, $\mathrm{SP}=.683$ ). Ini menunjukkan petanda yang positif kerana impak wabak COVID-19 turut memberi kesan kepada masyarakat tentang pemahaman mengenai penularan wabak penyakit berjangkit yang lain.

Kajian menunjukkan aspek yang perlu diberi perhatian mengikut pandangan responden adalah mengenai keadaan sungai di daerah mereka ketika tempoh $\mathrm{PKP}$ ini $(\mathrm{M}=3.59, \mathrm{SP}=.883)$, dan pengurusan sisa klinikal (contoh: sisa dari makmal, ubat-ubatan yang tidak digunakan dan pembalut luka yang tidak digunakan) oleh Pihak Berkuasa Tempatan (PBT) di kawasan kediaman mereka $(\mathrm{M}=3.72, \mathrm{SD}=.851)$.

Analisis seterusnya ialah analisis inferensi antara penelitian terhadap alam sekitar semasa situasi PKP COVID-19 dengan faktor sosio-demografi.

Seterusnya, Jadual 3 menunjukkan perbandingan persepsi masyarakat tentang status alam sekitar ketika PKP akibat pandemik COVID-19 berdasarkan faktor sosiodemografi terpilih.

JADUAL 3. Perbandingan antara penelitian terhadap alam sekitar semasa situasi PKP akibat pandemik COVID-19 dengan faktor sosio-demografi

\begin{tabular}{|c|c|c|c|c|c|}
\hline & Jantina & Responden (n) & $\operatorname{Min}(M)$ & $\begin{array}{l}\text { Sisihan piawai } \\
(S P)\end{array}$ & Nilai-p \\
\hline \multirow[t]{8}{*}{ Penelitian } & Lelaki & 183 & 4.07 & .61 & .024 \\
\hline & Perempuan & 324 & 4.18 & .49 & \\
\hline & $\begin{array}{c}\text { Status } \\
\text { Perkahwinan }\end{array}$ & & & & \\
\hline & Bujang & 240 & 4.17 & .49 & .254 \\
\hline & Berkahwin & 267 & 4.12 & .57 & \\
\hline & Lokasi & & & & \\
\hline & Bandar & 242 & 4.19 & .53 & .091 \\
\hline & Luar bandar & 265 & 4.10 & .55 & \\
\hline
\end{tabular}

Daripada segi jantina, ujian deskriptif menunjukkan responden perempuan mempunyai min skor $(\mathrm{M}=4.18$, $\mathrm{SP}=.49)$ yang lebih tinggi berbanding dengan responden lelaki $(\mathrm{M}=4.07, \mathrm{SP}=.61)$. Analisis ujian-t sampel bebas menunjukkan terdapat perbezaan yang signifikan $(p<.05)$ antara lelaki dan perempuan berhubung penelitian terhadap status alam sekitar ketika PKP akibat pandemik COVID-19. Keputusan ini secara tidak langsung menunjukkan responden perempuan mempunyai pandangan yang lebih positif berhubung status alam sekitar ketika PKP akibat pandemik COVID-19 berbanding responden lelaki. Ini menunjukkan perempuan lebih peka dengan status alam sekitar dan keputusan ini selari dengan keputusan Liu et al. (2016) yang mendapati perempuan 
mempunyai kesedaran yang lebih tinggi berbanding dengan lelaki tentang isu alam sekitar.

Jadual 3 juga menunjukkan perbandingan mengenai penelitian tentang alam sekitar ketika PKP akibat pandemik COVID-19 berdasarkan status perkahwinan. Ujian deskriptif menunjukkan responden bujang mempunyai min skor $(\mathrm{M}=4.17, \mathrm{SP}=.49)$ yang lebih tinggi berbanding responden yang sudah berkahwin $(\mathrm{M}=4.12, \mathrm{SP}=.57)$. Walaupun, analisis ujian-t sampel bebas menunjukkan tiada perbezaan yang signifikan ( $p$ $>$.05) antara mereka yang sudah berkahwin dan bujang berhubung tahap mereka tentang status alam sekitar ketika PKP akibat pandemik COVID-19. Walaupun keputusan kajian menunjukkan perbezaan yang tidak signifikan, data statistik deskriptif menunjukkan responden yang sudah berkahwin memperoleh skor yang lebih rendah kerana mereka berpandangan pencemaran udara di kawasan kediaman mereka masih merupakan satu isu.

Di samping itu, Jadual 3 turut menunjukkan perbandingan mengenai penelitian tentang alam sekitar ketika PKP akibat pandemik COVID-19 berdasarkan lokasi tempat tinggal. Ujian deskriptif menunjukkan responden yang menetap di bandar mempunyai min skor $(\mathrm{M}=4.19, \mathrm{SP}=.53)$ yang lebih tinggi berbanding dengan responden yang tinggal di luar bandar $(\mathrm{M}=4.10$, $\mathrm{SP}=.55)$. Keputusan ini menunjukkan petanda positif apabila min skor masyarakat bandar adalah lebih tinggi daripada penduduk luar bandar. Kajian lepas membuktikan penduduk bandar mempunyai persepsi yang tidak begitu baik terhadap status alam sekitar di bandar (Jialing \& Janet 2020), namun kajian ini telah membuktikan keputusan yang sebaliknya. Adalah jelas daripada kajian ini, PKP yang dikuatkuasakan akibat pandemik COVID-19 telah menghadkan pergerakan kenderaan di jalan raya, sekali gus memberi impak positif daripada sudut persepsi masyarakat bandar tentang status alam sekitar. Selanjutnya, ujian inferensi yang dilaksanakan melalui analisis ujian-t sampel bebas menunjukkan tiada perbezaan yang signifikan ( $p$ $>$.05) antara mereka yang tinggal di bandar dengan luar bandar berhubung dengan penelitian terhadap alam sekitar semasa situasi PKP akibat pandemik COVID-19.

Jadual 4 menunjukkan hubungan antara penelitian tentang status alam sekitar ketika PKP akibat pandemik COVID-19 dengan faktor pendapatan isi rumah dan bilangan isi rumah. Pekali korelasi untuk pendapatan ialah .044 sementara untuk bilangan isi rumah ialah .017 .

JADUAL 4. Hubungan antara penelitian terhadap alam sekitar semasa situasi PKP akibat pandemik COVID-19 dengan faktor sosio-demografi

\begin{tabular}{|c|c|c|c|c|}
\hline & & & Pendapatan & Bilangan isi rumah \\
\hline \multirow[t]{3}{*}{ Penelitian } & Korelasi Pearson & & .044 & .017 \\
\hline & Sig (2-tail) & & .327 & .710 \\
\hline & $\mathrm{n}$ & 507 & & \\
\hline
\end{tabular}

Analisis menunjukkan hubungan antara pendapatan isi rumah dengan penelitian tentang status alam sekitar ketika PKP akibat pandemik COVID-19 serta bilangan isi rumah dengan penelitian tentang status alam sekitar ketika PKP akibat pandemik COVID-19 adalah lemah. Tambahan pula, nilai- $p$ yang diperoleh ialah .327 dan .710, ini menunjukkan tiada hubungan yang signifikan antara pendapatan isi rumah dengan penelitian tentang status alam sekitar semasa ketika PKP akibat pandemik COVID-19 serta bilangan isi rumah dengan penelitian tentang status alam sekitar ketika PKP akibat pandemik COVID-19. Keputusan ini selari dengan beberapa kajian seperti Egondi et al. (2013) dan Qian et al. (2016).

\section{CADANGAN}

Keputusan kajian menunjukkan ketika PKP dikuatkuasakan akibat pandemik COVID-19, penggunaan bahan api fosil dan kenderaan di jalan raya dilihat berkurangan. Ini secara tidak langsung meningkatkan skor status alam sekitar dalam kalangan masyarakat Malaysia. Secara makro, skor ini memaparkan betapa kerajaan perlu menitikberatkan langkah ekonomi hijau, meneliti bidang keutamaan pembangunan ekonomi dan penguatkuasaan undangundang bagi mengawal alam sekitar daripada dicemari.

Di samping itu, keputusan kajian juga menunjukkan langkah penggunaan pengangkutan awam dalam kalangan masyarakat Malaysia perlu dipertingkatkan. Ini kerana 
masyarakat Malaysia memberi reaksi positif terhadap alam sekitar apabila PKP berjaya mengurangkan pergerakan kenderaan di jalan raya. Bagi merealisasikan cadangan ini, kempen berkongsi kenderaan perlu diperkasakan dengan lebih berkesan. Kementerian Pengangkutan boleh memainkan peranan penting bagi merangka pelan strategik ke arah menggalakkan masyarakat Malaysia menggunakan pengangkutan awam walaupun berdepan cabaran masyarakat yang lebih bergantung menggunakan kenderaan persendirian untuk urusan kerja atau harian.

Masyarakat Malaysia turut bimbang berhubung pengurusan sisa klinikal di kawasan mereka. Sehingga kini pengurusan sisa klinikal adalah berdasarkan Peraturan-Peraturan Kualiti Alam Sekeliling (Buangan Terjadual) 2005. Pihak Kementerian Alam Sekitar dan Air ketika ini memantau syarikat pengurusan sisa klinikal melalui sistem atas talian iaitu Electronic Schedule Waste Management System (eSWIS) bagi memastikan semua sisa klinikal diurus dengan sempurna dan sentiasa mematuhi sepenuhnya Akta Kualiti Alam Sekeling 1974 dan peraturan-peraturan di bawahnya. Justeru, Pihak Berkuasa Tempatan dan Jabatan Alam Sekitar di setiap negeri perlu memantap dan mengemas kini perundangan sedia ada serta melakukan pemantauan berterusan agar pengurusan sisa klinikal tidak menjadi satu isu kepada kesihatan awam.

\section{LIMITASI}

Kajian ini mempunyai beberapa limitasi. Pertamanya, daripada segi tatacara pengumpulan data responden diperoleh menggunakan saluran talian iaitu Facebook, Whatsapp, Telegram dan emel. Sungguhpun bilangan responden untuk kajian ini adalah memadai untuk membuat generalisasi, kategori persampelan masih memerlukan penambahbaikan daripada segi negeri, kumpulan umur dan status pekerjaan. Kedua, soalan terbuka turut boleh dikemukakan bersama dengan soalan tertutup untuk tujuan pemahaman yang lebih mendalam mengenai status alam sekitar di Malaysia. Antaranya berkaitan cadangan responden untuk memperbaiki pengurusan air, hutan dan tenaga di Malaysia.

\section{KESIMPULAN}

Hakikatnya, bencana dan pencemaran terhadap alam sekitar disumbangkan oleh beberapa faktor, antaranya campur tangan keterlaluan manusia, kegagalan mempraktikkan pembangunan mampan serta sambutan rendah masyarakat terhadap gaya hidup mesra alam. Ternyata masyarakat secara umum masih gagal menghayati dan menerapkan sepenuhnya matlamat pembangunan lestari rentetan kegagalan mengurus alam sekitar secara berhemah. Justeru, dalam usaha mengekang kemerosotan kualiti dan kemusnahan alam sekitar, masyarakat harus diberi kesedaran dan dipupuk dengan jati diri yang kukuh untuk bersama-sama memelihara dan memulihara alam sekitar yang kian terancam. Hal ini kerana, alam sekitar adalah komponen penting ke arah melahirkan masyarakat yang membangun secara mampan. Kajian mendapati status alam sekitar bertambah baik semasa PKP akibat pandemik COVID-19 khasnya disebabkan oleh penurunan penggunaan bahan api fosil dan pergerakan kenderaan di jalan raya. Pelan strategik untuk meneliti bidang keutamaan ekonomi negara, menggalakkan penggunaan pengangkutan awam dan pengurusan sisa klinikal merupakan tiga cadangan untuk meningkatkan status alam sekitar di Malaysia. Akhirnya, aplikasi 5R (Refuse, Reduce, Reuse, Recycle, Recovery atau 'Tolak, Kurangkan, Guna Semula, Kitar Semula dan Pemulihan) perlu diterapkan agar menjadi 'budaya' serta kelaziman dalam kehidupan seharian masyarakat Malaysia ke arah menikmati alam sekitar yang tidak tercemar, bersih, sihat, selesa dan menyamankan. Kajian pada masa hadapan dengan memperluaskan kategori persampelan dan disertai dengan soalan terbuka dijangka boleh meningkatkan lagi pemahaman mendalam mengenai status alam sekitar daripada persepsi masyarakat Malaysia.

\section{RUJUKAN}

Ahamad, F., Latif, M.T., Tang, R., Juneng, L., Dominick D. \& Juahir, H. 2014. Variation of surface ozone exceedance around Klang Valley, Malaysia. Atmospheric Research 139: 116-127.

Ahmad Shukri, Mohd Nain \& Rosman, Yusoff. 2003. Konsep, Teori, Dimensi dan Isu Pembangunan. Johor Baharu: Penerbit Universiti Teknologi Malaysia.

Aiken, S.R., Leinbach, T.R., Leigh, C.H. \& Moss, M.R. 1982. Pembangunan dan Persekitaran di Semenanjung Malaysia. Kuala Lumpur: Dewan Bahasa dan Pustaka.

Chin, Y.S.J., DePretto, L., Thuppil, V. \& Ashfold, M.J. 2019. Public awareness and support for environmental protection - A focus on air pollution in Peninsular Malaysia. PLoS ONE 14(3): e0212206.

Department of Statistics Malaysia. 2020. Current populations estimates Malaysia 2020. https://www.dosm.gov.my/v1_ index.php? $\mathrm{r}=$ column $/$ cthemeByCat\&cat $=155 \&$ bul_id $=\mathrm{OV}$ ByWjg5YkQ3MWFZRTN5bDJiaEVhZz09\&menu_id=L0 pheU43NWJwRWVSZklWdzQ4TlhUUT09.

Desa, A., Zanal, A., Hasnah, Jali, M.O.F.M. \& Omar, F. 2009. Persepsi masyarakat tentang alam sekitar di Wilayah Pembangunan Ekonomi Pantai Timur (ECER). Prosiding Perkem IV, Jilid 1. pp. 594-599.

D'Silva, J.L. \& Samah, A.A. 2018. Holistic well-being of Japanese retirees in Malaysia. Journal of International Studies 11(3): 95-103.

D’Silva, J.L., Mohamed, N.A., Samah, A.A., Dahalan, D. \& Shaffril, H.A.M. 2018. A systems thinking on developing 
holistic well-being among youth. Academy of Strategic Management Journal 17(5): 1-5.

Egondi, T., Kyobutungi, C., Ng, N., Muindi, K., Oti, S. \& Vijver, S.V. 2013. Community perceptions of air pollution annd related health risks in Nairobi slums. International Journal of Environmental Research and Public Health 10(10): 4851-4868.

Haliza Abdul Rahman. 2019. Pengetahuan, Kepercayaan dan Amalan Budaya Masyarakat Melayu Tradisional dalam Melestarikan Alam Sekitar. Universiti Malaysia Sabah Publisher. pp. 121-136.

Haliza Abdul Rahman. 2018. Defining the definition and aspiration of development in the contexts of environmental sustainablity. Asian Journal of Environment, History and Heritage 2(1): 267-278.

Haliza Abdul Rahman. 2017. Penglibatan komuniti dalam pengurusan sisa pepejal di Malaysia. Malaysian Journal of Environmental Management 16(1): 13-22.

Haliza Abdul Rahman. 2015. Public involvement in environment conservation and preservation. Dlm. Concept and Application of Community Interaction with Environment, disunting oleh Haliza Abdul Rahman, Rapeah Suppian. \& Norsuhana Abdul Hamid. Batu Pahat: Universiti Tun Hussein Onn Malaysia Publisher (UTHM). pp. 39-62.

Haliza Abdul Rahman. 2009. Masyarakat, etika persekitaran dan kelestarian alam sekitar. Prosiding Seminar Antarabangsa Ke-2 Ekologi, Habitat Manusia dan Perubahan Persekitaran. pp. 457-464.

Haliza Abdul Rahman. \& Mohammad Ghazi Ismail. 2012. Public involvement on environmental issues in Kuala Krai and Jeli District, Kelantan, Malaysia. International Journal of Applied Science and Technology 2(3): 233-244.

Jamil, N.K.H., Alias, Z. \& Muthu Kumarasamy, M. 2020. A conceptual paper: The mediating role of employee engagement in promoting green manufacturing practices in Malaysia. Postgraduate Research Symposium - January 2020: 213381684

Jialing, H. \& Janet, Z.Y. 2020. Beyond under the dome: An environmental documentary amplified public risk perception about air pollution in China. Journal of Risk Research 23(2): 227-241.

Liu, X., Wu, Y., Hu, Y., Liu, D., Zhang, J. \& Chen, C. 2016. Government employees' perception of urban air pollution and willingness to pay for improved quality: Across-sectional survey study in Nanchang, China. Environmental Science and Pollution Research 23(21): 22183-22189.

Makmom, A.A., Armi, A.S.M. \& Yee Jun, T. 2012. An overview of the air pollution trend in KlangValley, Malaysia. Open Environmental Sciences 6(1): 13-19.
Muller, J. 2020. Age Group Distribution of Internet Users Malaysia 2018. Accessed by https://www.statista.com/ statistics/981334/malaysia-internet-users-age-groupdistribution/.

Ng, C.K.C., Ooi, P.A.C., Wong, W.L. \& Khoo, G. 2020. First development of the Malaysian River Integrity Index (MyRII) based on biological, chemical and physical multi-metrics. Journal of Environmental Management 255: 109829.

O’Neill, R. \& McElroy, S. 2017. Targeting Value: Setting, Tracking and Integrating High-Impact Sustainability Goals. Accessed by https://sustainability.com/wp-content/ uploads/2017/12/sa-es-targeting-value.pdf

Qian, X., Xu, G., Li, L., Shen, Y., He, T. \& Liang, Y. 2016. Knowledge and perceptions of air pollution in Ningbo, China. BMC Public Health 16(1): 1138.

Rahman, H.A. 2018. Efforts and challenges in the application of environmental education in Malaysian school system. Asian Journal of Environment, History and Heritage 1(20): 61-70.

Rahman, N.H.A. \& Lee, M.H. 2020. Air pollutant index calendarbased graphics for visualizing trends profiling and analysis. Sains Malaysiana 49(1): 201-209.

Rasmussen, O.E. 1999. Putting quality of life to the test. Dlm. Urban Quality of Life: Critical Issues and Options, disunting oleh Lim, L.Y., Yuen, B. \& Low, C. Singapore: National University of Singapore. pp. 196-211.

Sentian, J., Herman, F., Yih, C.Y. \& Wui, J.C.M. 2019. Long-term air pollution trend analysis in Malaysia. International Journal of Environmental Impacts 2(4): 309-324.

Shafie, S.H.M. \& Mahmud, M. 2020. Aplikasi kerangka konseptual DPSIR USEPA bagi pencemaran udara bandar daripada kenderaan bermotor: Kajian kes Kuala Lumpur, Malaysia. E-Bangi 17(2): 77-90.

Suruhanjaya Komunikasi dan Multimedia 2018. Internet Users Survey 2018. https://www.mcmc.gov.my/skmmgovmy/ media/General/pdf/Internet-Users-Survey-2018.pdf.

Zaini Ujang. 2009. Minda Lestari: Pembangunan Negara dan Pemuliharaan Alam Sekitar. Skudai: Penerbit Universiti Teknologi Malaysia.

Institute for Social Science Studies

Universiti Putra Malaysia

43400 UPM Serdang, Selangor Darul Ehsan

Malaysia

*Pengarang untuk surat-menyurat; email: jld@upm.edu.my

Diserahkan: 2 Mei 2020

Diterima: 21 Ogos 2020 